JOSING: Journal of Nursing and Health

Volume 1, Nomor 1, Desember 2020

e-ISSN: 2745-7877

p-ISSN: 2746-0851

DOI: https://doi.org/10.31539/josing.v1i1.1166

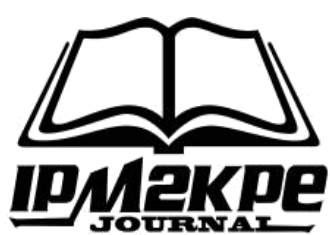

\title{
STIMULATION OF PRESCHOOL MOTOR DEVELOPMENT THROUGH BRAIN GYM AND PUZZLE
}

\author{
Panzilion $^{1}$, Padila $^{2}$, Asih Dewi Setyawati ${ }^{3}$, Harsismanto ${ }^{4}$, Andry Sartika ${ }^{5}$ \\ Muhammadiyah Bengkulu University ${ }^{1,2,3,4,5}$ \\ panzilion2020@gmail.com ${ }^{1}$
}

\begin{abstract}
The purpose of this study was to determine the effectiveness of brain Gymnastics and playing puzzles on improving the motor skills in preschool children in the work area of the Basuki Rahmad Health Center in Bengkulu. The Quantitative research design used the quasy experiment design, one group pre-post test equivalent without control design. The results of the univariate analysis with brain gymnastics and playing puzzles intervention showed the 15 respondents before doing brain gymnastics and puzzle, there were nine children (60\%) experiencing motor skills deviations and after giving therapy ten children (66.7\%) experienced standard motor skills. The bivariate results of the Wilcoxon test have a significant effect between before and after brain gymnastics and puzzle intervention with $p$-value $=0.001$ on motor development at the preschool children. It can conclude that an increase in the average motor picture before and after brain gymnastics and playing puzzles interventions in the Basuki Rahmad Community Health Center in Bengkulu.
\end{abstract}

Keywords: Brain gym, Puzzle, Motor, Preschool

\section{INTRODUCTION}

Optimization of children's growth and development in Indonesia has decreased, based on data as much as $16 \%$ of toddlers experience developmental disorders, both fine motor development, gross motor, hearing loss, and delayed speech, (Kemenkes, R.I, 2016). The main factor is the knowledge of mothers who are less qualified both in terms of quality and capacity to meet stimulation in the process of child development. This is evidenced by the results of Destiana (2017) showing that $65.7 \%$ was due to the mother factor not knowing how to stimulate children according to age and how to use child development assessment sheets. In line with the results of the mother's class training research on parental knowledge of child development has a $p$-value of 0.0001 in the treatment group and $p$-value of 0.409 in the control group. This shows that there is a significant influence for maternal classroom training on toddler development where the $p$-value $<0.05$ (Anita et al., 2018).

Delay in early detection can lead to deviation of growth and development, if it has happened this will be more difficult to intervene and will affect the child's continued growth and development. This reason is strongly recommended for parents to know how to provide appropriate stimulation according to the child's developmental age. Some researchers also found that the role of stimulation in a consistent manner by parent and environment can improve the optimization of the development for preschool age children (Senvi et al., 2018). 
The development in preschool children is the same as the age of other children which includes several aspects, one of the physical aspects for motoric. Physical language is defined as the body, body and body. Whereas motor is interpreted by movers (Padila et al., 2019). Therfore, the motor physical development of preschoolers can be interpreted as changes in body shape in preschoolers who affect movement skills (Madyastuti, 2016).

The motor skills of preschoolers begin to develop where children begin to use their fingers to write, draw, walk and run. The process of the stages of development of each child is the same, which is the result of the process of motor organ maturation. But in its achievement, every child has a different speed (Mubarok, Amini, 2020).

Late motor effects result in children's development being stunted and their growth and development not appropriate to their age. In the process of overcoming developmental delay in children a lot of stimulation is needed in play activities (Sari, et al., 2018). Play activity is one of the stimulations to optimize children's development. At this time, there are many types of educational games that can be used as interventions to improve children's motortic development, one of them is with a brain gym and playing puzzles, supported by playing instruments that are adapted to the age of the child so that children can be interested and able to stimulate the child's development optimally (Nurani, Mayangsri, 2017). Some stimulation can increase optimization of growth and development in preschool children include brain gym and puzzle (Sari et al., 2018).

Brain gym is a collection of simple movements that function to stimulate the development of all parts of the brain synergistically. This movement is also able to increase energy and support a positive attitude, reactivating the neural connections between the body and brain so as to facilitate the flow of electromagnetic energy throughout the body. These movements support electrical and chemical changes that stimulate a person's emotional and motor (Raetri, 2016). The movements in brain exercise have benefits such as balancing the brain, both the right brain and the left brain, so that not only does the logic and creativity of children become balanced, but it can also balance the child's motor skills (Sari et al., 2018). In line with Aprilasari's research results (2017) which states that there is a significant influence related to the application of Brain Gym Activities to Improve Child Development 4-6 Years at Marsudi Putro Kindergarten in Yogyakarta.

Playing puzzles can also stimulate motor development, especially fine motor skills in children aged 3-5 years, by playing puzzles preschoolers can practice accuracy, coordinating the movements of the eyes and hands of children. Therefore, children are not aware of fine motor skills continue to be trained and develop well. (Yuniati, 2018). In addition, when children play puzzles begin to learn to recognize shapes, how to play the puzzle so that it becomes an intact form. This game can be done in groups. When children play in groups, children can learn how to work together, how to adapt to their friends. This game can also make children become independent and become their own entertainment for children (Nurwita, 2019).

Bengkulu health department (Dinkes) (2019) states the data on growth and development of preschool-aged children based on community health centers (Puskesmas) working areas. The top ten preschoolers with the first rank are in the community health centers Basuki Rahmad working area of 733 preschoolers, with stimulation of development that has not yet been recorded. 
Based on surveys and initial interviews conducted by researchers in the working area of Basuki Rahmad Community Health Center in early March 2020, the results of interviews with 10 parents, all explained that they did not yet know what gymnastics or brain gym was, and no brain gym had ever been heard in the area. the work of the Basuki Rahmad Community Health Center. Likewise, the results of interviews with health center officials section growth and development. Meanwhile, to play a puzzle already exists but is rarely applied, because some respondents answered, their children prefer to watch gadgets such as cellphones rather than arranging puzzles. Based on the description above, this study aims to determine "The effectiveness of brain gymnastics (Brain gym) and playing Puzzle to Motor Development in Preschoolers in the work area of Basuki Rahmad Health Center in Bengkulu Province".

\section{RESEARCH METHOD}

This research is a quantitative study with a quasi experiment design, one group pre-post test equivalent without control design which is where the sample is taken nonrandomly with a total sample of 15 preschool age children. The sampling technique is using purposive sampling, with inclusion criteria, namely children who with the consent of parents are willing to be respondents, aged 4-5 years, do not have special needs, follow up to the end of the study and with the results of initial observations in the category of deviant and dubious with a range of values 7- 8.

The research was carried out in the working area of the Basuki Rahmad Public Health Center in Bengkulu from 3 March until 30 March, 2020. For measure the increase in children's motor used instruments or Pre-Screening Development Questionnaire (KPSP) aged 48-60 months, with two (2) times the first measurement: before being given brain exercises and playing puzzles, researchers first took measurements of fine and gross motor development using the KPSP questionnaire, after that researchers gave brain exercises and playing puzzles, for 30 minutes with two interventions at once (15 minutes brain gym, 15 minutes puzzles), for 4 weeks with 14 meeting times. The second measurement was carried out after 10 minutes of being given brain exercise and playing a puzzle at the 14th meeting, the researcher returned to the assessment using the same questionnaire when the measurement was initiated.

After calculating, entering the tabulation of the data, continued by testing the normality of the data, it was found that the data was not normally distributed then the Wilcoxon Test was performed to obtain the pvalues .

\section{RESULT}

\section{Univariate Analysis}

Table. 1

Frequency Distribution of Motor Images in Preschoolers Before and After Given Brain Gym Interventions (Brain Gym) and Playing Puzzle

\begin{tabular}{cccccc}
\hline & & \multicolumn{3}{c}{ Brain Gym Interventions and Playing Puzzle } \\
\cline { 3 - 6 } No & Category & Before & $\begin{array}{c}\text { Percentage } \\
(\%)\end{array}$ & After & $\begin{array}{c}\text { Percentage } \\
(\%)\end{array}$ \\
\hline 1 & Deviated & 9 & 60 & 0 & 0 \\
2 & Doubting & 6 & 40 & 5 & 33,3 \\
3 & Normal & 0 & 0 & 10 & 66,7 \\
\hline & Total & 15 & 100 & 15 & 100 \\
\hline
\end{tabular}

Source: Primary data that has been processed (2020) 
Based on table 1, it can be seen that prior to the intervention, most respondents have a deviant motor picture, which is $9(60 \%)$ respondents. After 4 weeks of intervention the majority of respondents had a normal motor picture of $10(66.7 \%)$ respondents.

Table. 2

Normality Test

\begin{tabular}{cccccc}
\hline Variable & Groups & & Mean & SD & p value \\
\hline Development & Brain Gym and & Before & 7,40 & 0,507 & 0,000 \\
AgesPreschool & Play Puzzle & After & 9,07 & 0,884 & 0,002 \\
\hline
\end{tabular}

Source: Primary data that has been processed (2020)

Table 2 shows that all Brain Gym and Puzzle games both before and after the intervention had data that were not normally distributed with $\mathrm{p}$-values $<0.05$. Thus the analysis carried out at a later stage is the Non-Parametric Test (Wilcoxon Test).

\section{Bivariate Analysis}

Table. 3

Scale of Preschool Children Motoric Development with Brain Gym Method and Playing Puzzle Before and After Intervention

\begin{tabular}{|c|c|c|c|c|c|}
\hline Variable & & $\mathrm{N}$ & Mean & SD & $P$ Value \\
\hline \multirow[t]{2}{*}{ Brain Gym and Play Puzzle } & Before & \multirow{2}{*}{15} & 7.40 & 0.50 & \multirow[b]{2}{*}{0.001} \\
\hline & After & & 9.07 & 0.88 & \\
\hline
\end{tabular}

Source: Primary data that has been processed (2020)

According to table 3, it describes that there was an increase in the average motor picture before and after brain exercise intervention (brain gym) and play puzzle that is from 7.40 with a standard deviation of 0.50 increased to 9.07 with a standard deviation of 0.88 . The results of statistical tests used the Wilcoxon test showed that there was a significant effect between before and after the brain gym intervention and playing puzzle with a p-value of 0.001 .

\section{DISCUSSION}

\section{Univariate Analysis}

Based on table 1, it can be seen that prior to the brain gym and puzzle intervention most of the respondents had a distorted motor picture of $9(60 \%)$ respondents. This is because in preschool children when researchers do the instructions the children do not pay attention even though it has been assisted by the teacher at the time of the direction and when doing the movements tend to arbitrarily without regard to the direction of the research team.

Respondents who experienced motor deviations as many as 9 people $(60 \%)$ were related to the questions below, which they could not do, namely for respondents aged 48 months question number 4 about instructions to place papers towards the researchers ordered, the reason being that the child did not want to follow Researcher's instructions but playing with his friend, question number 5 about children cannot draw and write according to instructions, question number 6 about arranging parts of the cube in this 
case is replaced by arranging puzzles up without dropping, on this question children can compile puzzles but still drop puzzles that are arranged.

After brain gym and puzzle intervention for 4 weeks most of the respondents had a normal motor picture of $10(66.7 \%)$ respondents. The above research results are in line with the theory of motor development, in preschool children (3-5 years) motor will develop in line with the optimization of stimulation provided by parents, the higher the age the more motor children develop, the movement will be well coordinated. This is because children continue to learn from past experiences and are supported by parental knowledge and the use of adequate health care facilities (Padila et al., 2019).

In line with Sari's research results (2018) states that before doing brain exercise $56.7 \%$ of preschoolers experience deviant motor development, because from the results of research these children fail to perform a series of simple activities designed to coordinate brain function through movement skills, speed of thinking and tend do not do orders.

Respondents who experienced motoric doubted as many as 5 people $(33.3 \%)$ they could not do, namely nonor 8 questions about children using pants, shirts and t-shirts without assistance, children could not do so because they were not accustomed to using clothes independently and question number 10 about children standing on one foot without holding hands, the child has not been able to do it because the child can not maintain balance so it falls.

Brain exercise is a simple exercise to facilitate learning activities and adjustments in daily activities, so that it can help balance the functions of the right brain and left brain and can perform motor activities in a balanced manner (Ade, 2015; Saichudin et al., 2015). According to Murtining (2018) motor stimulation is movement that stimulates small and large muscles. This movement requires careful coordination. The better motor movements so that children can be creative and have an optimal activity, this movement can be done through the activities of cutting gymnastics, cutting paper or by compiling a puzzle. Supported by Yuniati's research results (2018) about puzzles affecting the development of fine motor development in Preschool Age Children at Taqwa Mekarsari

Cimahi Kindergarten, it was found that 17 puzzle intervention groups, more than half the children examined before being given a puzzle intervention, deviated fine motor skills ie $(64.7 \%)$.

Brain gym and puzzle interventions affect the development of fine and gross motor skills in preschool children, because these two interventions can coordinate the movements of the hands, feet, train the balance between motor and eye so that the child is trained and develops well. In addition, when they brain gym and play puzzles children can practice to move freely, recognize shapes, swing their hands gently. Both of these interventions also encourage children to interact with peers when these interventions are given. From the observations of child researchers it is easier to recognize similarities and differences, such as how the colors are orange or yellow and the thick or non-thick lines in a piece correspond to the instructions in the image being played (Padila et al., 2019).

\section{Bivariate Analysis}

Based on table 3 above shows that there is an increase in the average motor picture before and after brain exercise intervention (brain gym) and play puzzle that is from 7.40 with a standard deviation of 0.50 increased to 9.07 with a standard deviation of 0.88 . The results of statistical tests using the Wilcoxon test showed that there was a 
significant effect between before and after the brain gym intervention and playing puzzle with a p-value of 0.001 .

In line with research conducted by Raetri (2016) research with brain gym intervention and other educational game tools. Obtained the results of Research Test I: Provision of brain gymnastics performed on group I respondents with the results of DDST data processing before and after treatment in group A by using Wilcoxon obtained $p$-value $=0.001$ ( $p$-value $<0.05)$, so it can be concluded that the administration of brain exercise affects the an increase in DDST values associated with an increase in motor skills of children aged 4-5 years.

From the statistical test results obtained $p$-value $=0.001$, it can be concluded that there is an increase in brain gym and playing puzzles, in preschool children in the work area of Basuki Rahmad Public Health Center in Bengkulu City. The results of this study are in line with the research of Maghfuroh (2018) it was found that there were differences before and after being given puzzle play therapy with a mean difference of 4.6. After the paired samples T-test statistical tests were obtained p values $(0.002)<\alpha$ 0.05 . Then there is the influence of the use of the method of playing puzzles for preschoolers before and after given puzzle play therapy.

In line with the research of Madyastuti (2016) concerning the effect of puzzle play therapy, it states that before the intervention of puzzle play therapy most respondents had sufficient fine motor development $(83.3 \%)$, with an average value of X1 =.17 and Standar Deviation 0.389. After doing puzzle play therapy all respondents have good fine motor development (100\%), with an average value of X2 $=3.00$ and Standar Deviation 0,000 . This means that there is an effect of puzzle play therapy on the development of fine motor development in preschool children (4-5 years). The results of this study are in line with the results of the synthesis of several studies which state that significant brain gym and puzzle are able to optimize motoric development in preschool children (Saichudin et al., 2015; Nurwita, 2019).

The results of this study indicated brain gym intervention and puzzle play have an effect on increasing the value of KPSP which is associated with increased motor skills in children aged 4-5 years old.

\section{CONCLUSION}

After brain gym and puzzle intervention for 4 weeks, most respondents have normal motor picture. There was an increase in the average motor scores in preschool children aged 4-5 years before and after brain gym intervention and playing Puzzle.

\section{SUGGESTIONS}

\section{Theoretical Suggestions}

It is hoped that it can be used as a reference in the development of nursing interventions, especially those related to motor stimulation with brain gym exercises and playing puzzles to overcome the gross and gross motoric categories of deviation and doubting preschool age in future.

\section{Practice Advice}

\section{For Research Sites}

To the Basuki Rahmad Puskesmas Bengkulu City can always apply and continue Brain Gym intervention and play Puzzle with a larger portion, scheduled, and documented in order to optimize the preschool age motor development. 


\section{For Future Researchers}

It is hoped that other researchers will be able to continue this study in children with special needs with a combination of brain gym methods and playing puzzles in motor optimization at preschool age.

\section{REFERENCES}

Ade, S. W. (2015). Pelaksanaan Senam Brain Gym terhadap Tingkat Kecerdasan Emosional Anak Usia Prasekolah (4-5 Tahun), Jurnal Ilmu Kesehatan Afiyah, 2(1). http://ejournal.stikesyarsi.ac.id/index.php/JAV1N1/article/view/36/127

Anita, L., Kusmiyati, K., \& Femmy, K. (2018). Pengaruh Pelatihan Kelas Ibu Balita terhadap Peningkatan Pengetahuan Orangtua tentang Tumbuh Kembang Anak di Puskesmas Teling Atas Kota Manado. https://ejurnal.poltekkes-manado.ac.id/cgisys/suspendedpage.cgi

Aprilasari, A. (2017). Penerapan Aktivitas Brain Gym untuk Meningkatkan Perkembangan Anak Usia 4-6 Tahun di TK Marsudi Putro Yogyakarta. http://repository.unjaya.ac.id

Destiana, D. (2017). Kemampuan Ibu Melakukan Stimulasi untuk Perkembangan Balita. Jurnal Ilmu Kesehatan 6(1). https://www.ejurnaladhkdr.com/index.php/jik/article/view/155

Dinas Kesehatan Provinsi Bengkulu. (2019). Profil Kesehatan Provinsi Bengkulu. Bengkulu

Kemenkes RI. (2016). Profil Kesehatan Indonesia. Jakarta: Kemenkes RI

Madyastuti, L. (2016). Pengaruh Terapi Bermain Puzzle terhadap Perkembangan Motorik Halus dan Kognitif Anak Usia Pra sekolah (4-5 tahun). Juornals Nesr Community. 07(02). http://journal.unigres.ac.id/index.php/JNC/article/view/265

Maghfuroh, L. (2018). Metode Bermain Puzzle Berpengaruh pada Perkembangan Motorik Halus Anak Usia Prasekolah. Jurnal Endurance 3(1), 55-60. http://ejournal.kopertis10.or.id/index.php/endurance/article/download/2488/878

Mubarok, M., \& Amini, A. (2020). Kemampuan dalam Mengurutkan Angka melalui Metode Bermain Puzzle. Jurnal Obsesi : Jurnal Pendidikan Anak Usia Dini, 4(1), 77-89. https: DOI: 10.31004/obsesi.v4i1.221

Murtining, H. (2018). Meningkatkan Keterampilan Motorik Halus dengan Berbagai Media Pada Kelompok TK Dharma Wanita. Jurnal Care, 6(1), 28-40. https : ejournal.unimpa.ac.id

Nurani, Y., \& Mayangsri, T. (2017). Pengembangan Model Kegiatan Sentra Bermain dalam Mengembangkan Kreativitas Anak Usia Dini. JPUD- Jurnal Pendidikan Usia Dini, 11(2), 386-400. https://doi.org/10.21009/JPUD.112.15

Nurwita, S. (2019). Pemanfaatan Media Puzzle dalam Mengembangkan Motorik Halus Anak. Jurnal Pendidikan Tambusai, 3(4), 803-810. http Article\%20Text-546-210-20190820.pdf

Padila, P., Andari, F., \& Andri, J. (2019). Hasil Skrining Perkembangan Anak Usia Toddler antara DDST dengan SDIDTK. Jurnal Keperawatan Silampari, 3(1), 244-256. https://doi.org/https://doi.org/10.31539/jks.v3i1.809

Raetri, H. K. (2016). Perbedaan Pengaruh Pemberian Senam Otak dengan Alat Permainan Edukatif terhadap Peningkatan Motorik Halus Anak Usia 4-5 Tahun. http://digilib.unisayogya.ac.id/2222/1/naskah\%20publikasi\%20ratri.pdf 
Saichudin, S. (2015). Meningkatkan Kemampuan Kognitif melalui Metode Eksperimen pada Anak Usia Dini Di PAUD Bunga Jempa UPTD SKB Kabupaten Lebong. http://repository.unib.ac.id/8547/2/I,II,III,I-14-eri-FK.pdf

Sari, L. P. (2018). Pengaruh Senam Otak terhadap Peningkatan Motorik Halus pada Anak Usia 3-4 Tahun di Paud Mawar Tlogomas Malang. Nursing News, 3(1). https://publikasi.unitri.ac.id/index.php/fikes/article/view/794

Senvi, F., Ahmad, Y., \& Dadang, P. (2018). Gambaran Pengetahuan Ibu tentang Stimulasi Tumbuh Kembang Balita di wilayah Kerja Puskesmas Guntur. Jurnal Kesehatan Bhakti Husada, 5(1). http://e-journal.akperakbidbhaktihusada.ac.id/index.php/jurnal/article/view/20

Yuniati, Y. (2018). Pengaruh Penggunaan Alat Permainan Edukatif Jenis Puzzle terhadap Perkembangan Motorik Halus Anak Usia Prasekolah di Taman KanakKanak at Taqwa Mekarsari. Cimahi Jawa Baratm 11(1). http://ejournal.poltekkesternate.ac.id/ojs 